\title{
PERANAN MAKET PINTARKU UNTUK ASPEK PERKEMBANGAN ANAK DI TK ABA KALANGAN BANTUL DIY
}

\author{
Meyda Setyana Hutami ${ }^{1}$, Suyadi ${ }^{2}$ \\ Fakultas Ilmu Tarbiyah dan Keguruan, UIN Sunan Kalijaga Yogyakarta \\ Email: meydasetyana3@gmail.com ${ }^{1}$,Email: suyadi@uin-suka.ac.id ${ }^{2}$
}

\begin{abstract}
Abstrak
Penelitian ini bertujuan untuk mengembangkan aspek perkembangan bagi anak usia dini melalui penerapan penggunaan alat permainan maket pintarku di TK ABA Kalangan Bantul DIY. Jenis penelitian yang digunakan adalah penelitian kualitatif. Metode pengumpulan data yang digunakan adalah melalui metode observasi, wawancara, dan dokumentasi. Alat permainan maket pintarku media pembelajaran ini sudah layak digunakan karena alat permainan ini multiguna dan dapat digunakan dalam menstimulasi aspek-aspek perkembangan peserta didik. Alat permainan ini merupakan alat permainan yang efektif guna mengenalkan konsep angka, huruf, serta warna yang dibuat menarik yang tidak membosankan bagi anak .Seiring dengan penggunaan alat permainan edukatif (APE) maket pintarku ini dapat meningkatkan seluruh aspek perkembangan anak pada kelompok B2 di TK ABA Kalangan Banguntapan Bantul DIY pada tahun ajaran 2019/2020.
\end{abstract}

Kata Kunci : aspek perkembangan, konsep angka dan huruf, maket pintarku

\begin{abstract}
This research aims to develop a developmental aspect for early childhood through the application of the use of a game tool mockup my door in the TK ABA circles DIY. The type of research used is qualitative research. The data collection methods used are through observation methods, interviews, and documentation. My game tool mockup Media learning is already worth using because the game tool is multipurpose and can be used in stimulating aspects of learners ' development. This game tool is an effective game tool to introduce the concept of numbers, letters, and colors that are made interesting that is not boring to the child. Along with the use of this educational game tool (APE) mockup my door can improve all aspects of children's development in the group of B2 in ABA kindergarten among Banguntapan Bantul DIY in the school year 2019/2020.
\end{abstract}

Keywords: Aspects of progression, concept of numbers and letters, mockup my Door

(C) 2019 Meyda Setyana Hutami ${ }^{1}$, Suyadi $^{2}$ Under the license CC BY-SA 4.0

http://jurnal.upmk.ac.id/index.php/pelitap 


\section{PENDAHULUAN}

Masa kecil anak dijumpai melalui masa bermain, dengan bermain anak akan lebih mudah dalam mengingat memori masa kecilnya pada saat anak bermain. Disamping itu, anak juga dapat belajar berinteraksi dan berkomunikasi dengan teman sebayanya. Di dalam masa bermain, anak tidak hanya menggunakan kegembiraannya hanya dengan bermain, karena bermain juga dapat mengajak anak untuk berproses dalam belajar. Diketahui bahwa pada masa anakanak awal dalam bermain dan belajar dapat memberi kesempatan pada anak untuk memperkaya pengalaman anak sehingga anak mendapatkan banyak pembelajaran melalui bermain.

Alat permainan edukatif adalah jenis permainan atau media untuk belajar yang bertujuan untuk memberikan nilai edukatif untuk peserta didik. Menurut Dian (2015:51) menyatatakan bahwa permainan edukatif merupakan suatu alat permainan yang bertujuan untuk memberikan nilai positif bagi pendidikan yang bertujuan untuk mengembangkan aspek yang dimiliki oleh anak paud.

Menurut penulis alat permainan edukatif merupakan suatu alat atau permainan yang dapat digunakan untuk mengembangkan dan menumbuhkan perkembangan anak yang mengandung nilai pendidikan. Dari alat permainan yang mempunyai nilai edukatif itulah mampu mengembangkan aspek-aspek kecerdasan pada anak.

Guru tidak hanya mengajar di Taman kanak-kanak, tetapi seorang guru juga harus dapat melaksanakan kegiatan pembelajaran yang bernilai edukatif. Untuk mencapai hal tersebut, seorang guru memerlukan sebuah media atau alat yang biasa disebut dengan alat permainan edukatif. Permainan edukatif tersebut digunakan sebagai media untuk belajar anak dengan cara yang menyenangkan. Untuk itu selayaknya guru memiliki atau memfasilitasi dan dapat membuat alat permainan secara kreatif dan inovatif yang disesuaikan dengan pembelajaran.

Dalam melakukan aktivitas belajar-mengajar, pembelajaran 
anak tidak hanya diberikan secara monoton, tetapi perlu adanya inovasi dan kreatifitas dari guru melalui lat permainan yang dibuatnya serta dapat berguna untuk mengembangkan aspek perkembangan anak. Oleh karena itu agar dapat menstimulasi tumbuh dan kembang anak perlu kreatifitas dan inovasi dari pendidik maupun orangtua dalam membuat alat permainan yang menarik bagi anak tanpa mengurangi nilai edukasinya. (Riany Ariesta, 2009:1)

Ada beberapa syarat dan ciri yang harus terpenuhi dalam pembuatan alat permainan edukatif, yaitu: a. Media permainan tersebut ditujukan untuk anak usia dini. Dalam pembuatan alat permainan edukatif harus menggunakan bahan yang tidak membahayakan bagi anak. b.Difungsikan agar dapat mengembangkan aspek-aspek perkembangan anak TK. Alat permainan edukatif yang baik adalah yang mengandung nilai enam aspek perkembangan. c. Dapat digunakan dengan multifungsi atau multiguna, $d$. Aman dan tidak berbahaya untuk anak. Dalam pembuatan alat permainan ini hindari untuk menggunakan bahan yang tajam yang berbahaya bagi anak. e. Dirancang untuk memotivasi pembelajaran dan kreativitas anak. Disamping itu, juga harus menarik dan mencolok warna. $f$. Mengandung nilai edukatif.

Pendidik PAUD bukan hanya menjadi fasilitator dalam pembelajaran di lembaga PAUD , tetapi juga bertujuan untuk membentuk anak yang berkualitas maka harus memahami berbagao metode serta media yang dibutuhkan saat pembelajaran yaitu salah satu media yang penting untuk diadakan adalah alat permainan edukatif, sebab dengan media ini anak akan belajar dengan cara yang mengesankan dan menyenangkan.

Menurut Zaman, dkk (2005:5.15) alat pembelajaran bagi anak tidak melalui APE saja tetapi bisa dengan menggunakan media pembelajaran seperti audio, visual, audiovisual maupun media pembelajaran lainnya yang dilaksanakan di kelas maupun diluar kelas ada tahap-tahap atau prosedur pokok yang harus dilalui 
sebagai berikut: a)Tahap Persiapan.

Sebagai seorang guru tahap awal adalah mempersiapkan dan merencanakan segala materi yang akan disampaikan kepada peserta didik, selanjutnya guru mempersiapkan media yang akan digunakan, guru mempersiapkan ruangan serta segala peralatan yang akan digunakan, guru mengkondisikan anak. b) Tahap Pelaksanaan. Dalam hal tema yang akan disampaikan harus disesuaikan dengan perkembangan anak. c) Tahap Evaluasi. Setelah kegiatan pembelajaran selesau, tahap selanjutnya adalah guru mengadakan evaluasi terhadap hasil belajar anak. d) Tahap Tindak Lanjut. Yaitu guru memberikan penjelasan bagaimana cara anak mampu memahami tentang topic yang telah disampaikan.

Penulis memilih menggunakan alat permainan Maket Pintarku karena anak usia dini menyukai permainan dan permainan tersebut dapat dibuat sesuai kreatifitas guru sehingga anak merasa tertarik ingin memainkannya, penulis mencoba mempraktekkannya di TK ABA Kalangan. Melalui permainan tentu akan membuat belajar terasa menyenangkan. Alat permainan adalah media belajar yang digunakan untuk menstimulasi kemampuan kognitif, fisik motorik, serta bahasa anak. Permainan ini menggunakan papan dalam permainannya. Alat permainan ini dibuat secara mudah, menarik dan jika dimainkan anak akan menyenangkan, aman, dan sesuai dalam pembelajaran kognitif fisik motorik serta bahasa anak. Selain mengembangkan kemampuan kognitifnya, permainan maket pintarku ini juga mengembangkan kemampuan fisik motorik, bahasa, seni, nilai agama dan moral serta sosial emosional anak.

Media bermain maket pintarku ini dibuat menggunakan kartu gambar dan kartu huruf dengan tujuan dapat melatih anak dalam mengembangkan aspek kognitif serta kemampuan bahasanya melalui gambar yang dilihatnya. Dengan melihat gambar pula anak dapat menambah kosakata pada anak. Hurlock (1995) berpendapat bahwa "bahasa mencakup setiap sarana komunikasi dengan menyimbolkan pikiran dan perasaan untuk 
menyampaikan makna kepada orang lain.

Dalam memilih alat permainan, guru sebaiknya memperhatikan manfaat alat permainan yang digunakan. Menurut Eliyawati (2005) alat permainan edukatif berfungsi mendorong anak untuk beraktifitas dan bersifat konstruktif atau menghasilkan sesuatu.

Maket pintarku ini merupakan salah satu alat permainan edukatif yang terbuat dari kertas karton dan bahan bekas yang masih bisa digunakan untuk bermain yang kemudian juga dihias. Alat permainan ini diciptakan untuk dimainkan oleh anak usia 5-6 tahun guna untuk mengembangkan kemampuan kognitifnya. Alat permainan papan otak atik ini berbentuk persegi panjang yang kemudian diberi kertas warna-warni untuk menghiasnya. Pada saat anak memainkan alat permainan ini anak dapat mengembangka kemampuan kognitif, bahasa, fisik motorik, dan seni.

\section{METODE PENELITIAN}

Penelitian ini adalah
penelitian deskriptif kualitatif

adalah penelitian yang digunakan untuk mendeskripsikan dan menganalisis fenomena, peristiwa, aktivitas sosial, sikap, kepercayaan, presepsi, dan orang secara individual maupun kelompok (Sukmadinata, 2009:53-60).

Tujuan penelitian deksriptif kualitatif adalah mendefinisikan suatu keadaan atau fenomena secara apa adanya. Dalam hal ini yaitu mengamati penggunaan alat permainan edukatif (APE) maket pintarku pada anak usia 5-6 tahun, memperoleh informasi mengenai penggunaan maket pintarku pada anak usia 5-6 tahun, dan untuk mendapatkan rekaman gambar, rekaman suara serta mengambil foto saat kegiatan menggunakan APE maket pintarku yang dilaksanakan pada TK ABA Kalangan Tahun Ajaran 2019/2020.

\section{Jenis Penelitian}

Penelitian ini menggunakan pendekatan kualitatif penelitian lapangan (field research) sebuah penelitian dengan prosedur penelitian yang menggali data dari lapangan untuk kemudian dicermati dan disimpulkan. Adapun sifat penelitian ini bersifat 
kualitatif atau Naturalistik.

(Nasution S.,1991:5)

\section{Waktu dan Tempat Penelitian}

Waktu dan tempat penelitian ini dilaksanakan pada hari Rabu 20 November 2019 di TK ABA Kalangan, Kelurahan Baturetno, Kecamatan

Banguntapan, Kabupaten Bantul, DIY.

\section{Subjek Penelitian}

Subjek penelitian adalah kelompok B2 TK ABA Kalangan Kelurahan Baturetno, Kecamatan Banguntapan, Kabupaten Bantul, DIY tahun ajaran 2018/2019 yang berjumlah 21 orang dengan siswa perempuan 7 orang dan siwa lakilaki ada 14 orang.

\section{Prosedur}

Dari data penelitian yang dilakukan, peneliti memilih triangulasi. Menurut Lexy J. Moleong (2014:330), triangulasi merupakan tekhnik pemeriksaan keabsahan data yang dimanfaatkan untuk keperluan pengecekan data atau sebagai pembanding terhadap data yang telah diperoleh. Dalam tekhnik pemeriksaan menggunakan :

1.Triangulasi sumber, yaitu peneliti menguji kebenaran data dengan cara mengecek data yang telah diperoleh melalui beberapa sumber. Untuk itu, peneliti melakukan wawancara dengan kepala sekolah dan wali kelas kelompok B2 untuk mendapatkan data mengenai penggunaan alat permainan maket pintarku dalam mengembangkan kemampuan kognitif dan diuji kebenarannya. 2.Triangulasi metode, yaitu peneliti menguji dengan cara mengecek data kepada sumber yang sama dengan metode yang berbeda, yaitu dengan melakukan observasi, wawancara, dan dokumentasi. Untuk itu, peneliti melakukan observasi mengenai aktivitas anak dalam kegiatan pembelajaran, melakukan wawancara mengenai penggunaan alat permainan edukatif dan dokumentasi saat kegiatan pembelajaran berlangsung dengan menggunakan alat permainan maket pintarku.

Data, Intrumen, dan Teknik Pengumpulan Data

Sumber data dalam penelitian ini terdiri dari sumber data primer dan sumber data sekunder. Sumber data primer dalam penelitian ini adalah kepala lembaga serta guru yang ada di 
TK ABA Kalangan Baturetno, Banguntapan, Bantul DIY. Sumber data sekunder pada penelitian ini adalah dokumen yang berguna untuk memperkuat data dari sumber data primer.

Instrumen pengumpulan data pada penelitian ini adalah peneliti dengan menggunakan pedoman wawancara, observasi dan dokumentasi. Instrumen penelitian merupakan alat bantu penelitian yang dapat digunakan untuk mengumpulkan data agar penelitian lebih mudah dan sistematis.

\section{Menurut Sugiyono}

mengenai tekhnik pengumpulan data (2014:224), merupakan langkah yang paling strategis dalam penelitian, karena tujuan utama dari penelitian adalah mendapatkan data”. Tekhnik pengumpulan data yang dilakukan dalam penelitian ini menggunakan wawancara, observasi dan dokumentasi. Peneliti melakukan wawancara dengan guru kelompok B, selain itu peneliti mengamati guru dan anak saat proses pembelajaran di kelas, dan peneliti mengambil dokumentasi berupa foto dan arsip guru di TK
ABA Kalangan. Yang menjadi instrumen dalam penelitian ini adalah peneliti sendiri.

\section{Teknik Analisis Data}

Analisis data pada penelitian ini menggunakan model Miles and Huberman (Sugiyono, 2013:338). Analisis data yang digunakan dengan cara menganalisis keseluruhan dari data hasil wawancara, observasi, dan dokumentasi yang penulis lakukan yang berkaitan dengan peranan penggunaan alat permainan maket pintarku di TK ABA Kalangan dengan menggambarkan hasil yang diperoleh menggunakan kalimat-kalimat sesuai langkah analisis data menurut Miles dan Huberman yaitu yang terdiri dari koleksi data, reduksi data, penyajian data dan verifikasi.

\section{HASIL PENELITIAN DAN PEMBAHASAN}

Alat permainan adalah media bermain yang dapat digunakan oleh anak untuk dapat mengeksplore dirinya dengan bermain, sehingga mampu memperkaua pengalamannya sebab anak belajar melalui bermain. Sedangkan Alat 
Permainan Edukatif adalah media permainan yang dirancang untuk mengembangkan aspek kecerdasan pada anak. Usep Kustiawan, 2016:7)

Subyek dalam penelitian ini adalah 1 guru dan 21 anak yang terdiri dari 13 anak laki- laki dan 8 anak perempuan usia 5-6 tahun di TK ABA Kalangan Banguntapan Bantul DIY.

Peneliti mengembangkan alat permainan edukatif (APE) di TK ABA Kalangan Banguntapan Bantul DIY agar dapat mengembangkan aspek perkembangan yang ada pada anak usia dini pada usia 5-6 tahun.

Berdasarkan data observasi disimpulkan bahwa alat permainan maket pintarku sebagai salah satu alternatif pembelajaran untuk mengembangkan aspek-aspek perkembangan anak yang mudah, aman, menyenangkan serta menarik bagi anak.

Berdasarkan praktek yang dilakukan secara langsung terhadap alat permainan maket pintarku yang dilakukan oleh anak kelompok B di TK ABA Kalangan diperoleh temuan yaitu: kemampuan Nilai Agama dan
Moral anak yaitu melalui anak mengenal macam-macam buahbuahan yang merupakan ciptaan Allah, (2) kemampuan kognitif yaitu mencari jejak/labirin dari rumah menuju ke kebun apel, (3) kemampuan bahasa yaitu menyebutkan huruf-huruf yang ada pada kartu gambar yang berkaitan dengan gambar buahbuahan, (4) kemampuan fisik motorik dijumpai pada anak saat menempel buah apel pada pohonnya, (5) kemampuan seni dijumpai anak pada saat anak menyanyikan lagu yang berkaitan dengan buah-buahan, kemampuan sosial dan emosional anak dijumpai pada saat anak bermain alat permainan yang telah disediakan sesuai aturan serta bermain secara kooperatif dengan teman.

Kelebihan yang didapatkan dari penggunaan alat permainan ini selain dapat menstimulasi perkembangan kognitif anak juga dapat mengembangkan aspekaspek yang lain yang berkaitan dengan aspek perkembangan pada anak usia dini. Kelebihan dari alat permainan tersebut adalah: (1) dapat memberikan stimulasi pada 
kemampuan fisik motorik anak yaitu kekuatan kelenturan anak saat memberikannya lem pada gambar apel dilanjut menempelnya, (2) kemampuan kognitif anak yaitu saat anak menunjukkan jalan menuju kebun apel dengan menggunakan tutup botol bekas selain itu anak juga dapat memahami bentuk persegi panjang melalui jalan yang dilewatinya, (3) kemampuan bahasa anak yaitu saat anak menyebutkan nama buah yang ada pada kartu gambar,

kemampuan sosial emosional anak yaitu saat anak mematuhi aturan permainan, (5) kemampuan nam (nilai agama dan moral) saat anak dapat menyebutkan bahwa buah merupakan ciptaan Allah, (6) kemampuan seni anak yaitu saat anak dapat membedakan perbedaan dari warna buah yang ada pada kartu gambar.

Berdasarkan data yang diperoleh alat permainan maket pintarku merupakan media bermain yang dapat mengandung 6 aspek perkembangan anak usia dini serta alat permainan ini merupakan alat permainan yang efektif guna mengenalkan konsep angka, huruf, serta warna yang dibuat menarik yang tidak membosankan bagi anak.

APE yang digunakan oleh guru dalam proses pembelajaran sebagai media belajar harusnya APE yang mengandung nilai pendidikan yaitu APE yang dapat mengembangkan aspek kecerdasan pada anak.

Penggunaan media permainan seperti APE saat pembelajaran dapat mengembangkan aspek kecerdasan anak. tentunya tujuan yang ingin dicapai dalam pembelajaran dapat terlaksana dengan baik. Berdasarkan hasil wawancara dan observasi yang telah dijelaskan bahwa penggunaan APE di dalam pembelajaran guru sudah sesuai. Yaitu guru mengikuti prosedurprosedur yang sesuai dengan pendapat Zaman, dkk (2005:15) meliputi tahap persiapan, tahap pelaksanaan, tahap evaluasi, dan tahap tindak lanjut.

Berdasarkan hasil penggunaan APE maket pintarku dapat diberi kesimpulan bahwa penggunaan alat permainan ini dapat mengembangkan beberapa aspek perkembangan anak 
diantaranya aspek perkembangan NAM, kognitif, bahasa, fisik motorik, seni, dan sosial emosional.

Anak usia dini ialah anak usia antara $0-6$ tahun yang memiliki pertumbuhan dan perkembangan luar biasa sehingga memiliki sebuah ciri khas pada setiap masing-masing individu, diantaranya adalah pola pertumbuhan dan perkembangan, intelegensi, sosial emosional, bahasa, dan komunikasi yang khusus sesuai dengan tingkat pertumbuhan dan perkembangan anak.

Penggunaan metode bermain berbantuan maket pintarku harus dirancang dengan baik agar dapat mengembangkan kemampuan atau aspek-aspek perkembangan pada anak usia dini. Langkah-langkah penerapan metode bermain maket pintarku seperti mempersiapkan topik/tema, mempersiapkan alat bermain yaitu maket pintarku, mempersiapkan lagu yang disesuaikan dengan tema, dan mempersiapkan alat mainnya berupa kartu angka, kartu huruf, serta kartu gambar. Selain itu, guru bisa memberikan reward/hadiah kepada anak yang telah melakukan permainan dengan tertib dan benar. Reward tersebut bisa berupa tepuk tangan atau pemberian stiker bintang yang ditempelkan pada baju anak.

APE merupakan media yang sesuai untuk digunakan pada anak pada usia dini, karna bagi anak usia dini melalui metode belajar sambil bermain akan mempermudah anak untuk menerima pembelajaran yang disampaikan oleh pendidik. Bermain merupakan prinsip dasar pendidikan anak usia dini, sehingga wajar apabila bermain menjadi salah satu metode yang baik dilakukan di TK. Bermain memiliki kelebihan yaitu dapat merangsang perkembangan motorik anak, merangsang perkembangan berfikir anak, melatih

kemandirian anak, dan melatih kedisiplinan anak Priyono (dalam Astuti, 2012:9).

Seiring dengan stimulasi melalui APE maket pintarku ini perkembangan kognitif serta bahasa anak dapat terstimulasi dengan baik. Selain itu juga bermanfaat untuk perkembangan 
otak, struktur otak anak mulai dapat berkembang setelah lahir.

Pemanfaatan APE yang digunakan oleh guru sebagai media pembelajaran sebaiknya mengacu kepada perkembangan anak dan multiguna karena agar dapat menstimulasi seluruh aspek perkembangan anak. Dalam pembuatan APE guru juga harus dituntut kreatif dan menggunakan bahan-bahan yang tidak berbahaya serta dapat menarik bagi anak. Dalam pembuatan APE juga harus disesuaikan dengan SPPA dan indikator pencapaian

perkembangan anak.

\section{SIMPULAN}

\section{Berdasarkan}

hasil observasi penggunaan alat permainan edukatif (APE) maket pintarku media pembelajaran ini sudah layak digunakan karena alat permainan ini multiguna dan dapat digunakan dalam menstimulasi aspek-aspek perkembangan peserta didik.

Kegiatan pembelajaran atau alat main yang digunakan guru melalui media pembelajaran maket pintarku anak sudah dapat terstimulasi secara sistematik dan berkelanjutan.

Penggunaan metode bermain berbantuan maket pintarku harus dirancang dengan baik agar dapat mengembangkan kemampuan atau aspek-aspek perkembangan pada anak usia dini. Langkah-langkah penerapan metode bermain maze pintarku mulai dari mempersiapkan topik/tema, mempersiapkan alat bermain yaitu maket pintarku, mempersiapkan lagu yang disesuaikan dengan tema, dan mempersiapkan alat mainnya berupa kartu angka, kartu huruf, serta kartu gambar.

\section{DAFTAR PUSTAKA}

Astuti, Kade. (2012). "Penerapan Metode Bermain dengan Kartu Huruf untuk Meningkatkan Perkembangan Bahasa Anak Kelompok A TK Sutha Kertya Banjar Tegehan Kecamatan

Banjar Kabupaten Buleleng Semester II Tahun Pelajaran 2011/2012”. Jurusan Pendidikan Guru Pendidikan Anak Usia Dini. Undiksha Singaraja

Badru Zaman. (2007). Media dan Sumber Belajar TK. Jakarta: Penerbit Universitas Terbuka.

Badru Zaman. (2006). Pengembangan Alat Permainan Edukatif untuk Anak Taman Kanak-kanak, (Online) 
Departemen Pendidikan Nasional. (2003). Pembelajaran di Taman Kanak-kanak Didaktik Metodik di TK. Jakarta

Dian Wulandari. (2015). Evaluasi Penerapan Beyond Centers and Cicrle Time Pada Pembelajaran Kelompok B. Yogyakarta : Fakultas Ilmu Pendidikan UNY.

Eliyawati, C. (2005). Pemilihan dan Pengembangan Sumber Belajar Pada Anak Usia Dini. Jakarta: Departemen Pendidikan Nasional

Hurlock, E. (1995). Perkembangan Anak. Jakarta: Erlangga.

Juliansyah Noor. (2013). Metodologi Penelitian, Jakarta: Kencana,

Lexy J. Moleong. (2010). Metodologi Penelitian Kualitatif. Bandung: Remaja Rosdakarya.

Moleong, Lexi. J. (2013). Metode Penelitian Kualitatif. Bandung: PT. Remaja Rosdakarya

Nasution S. (1991). Metode penelitian Naturalistik Kualitatif , Bandung: Tarsito.

Riany Ariesta. (2009). Alat Permainan Edukatif Lingkungan Sekitar untuk Anak Usia 0-1 Tahun, Bandung: PT. Sandiarta Sukses.

Sugiyono. (2001). Metode Penelitian Kunatitatif Kualitatif Dan $R \& D$. Bandung: Alfabeta

Susanto Ahmad. (2011). Perkembangan Anak Usia Dini. Jakarta: Kencana

Usep Kustiawan. (2016). Pengembangan Media Pembelajaran Anak
Usia Dini, Malang: Gunung Samudera,.

Badru Zaman. (2011). Pengembangan Alat Permainan Edukatif Di Lembaga Pendidikan Anak Usia Dini (PAUD). 